\title{
PREVALENCE AND RISK FACTORS FOR HEPATITIS C VIRUS INFECTION AMONG GENERAL POPULATION IN LUXOR GOVERNORATE, EGYPT
}

By

\author{
Ahmed M. El-Adly*1, Ahmed Wardany ${ }^{1}$ and Mohamed F. M. Morsy ${ }^{2}$ \\ ${ }^{1}$ Botany and Microbiology Department, Faculty of Science, Al-Azhar University, (Assiut) \\ ${ }^{2}$ Hepatology and gastroenterology and infectious diseases Department, Faculty of \\ Medicine, Al-Azhar University, (Assiut) \\ *Corresponding author: El-Adly AM, Botany \& Microbiology Department, Faculty of \\ Science, Al-Azhar University, 71524 Assiut, Egypt,
}

Email: ahmedeladly.ast@azhar.edu.eg, Tel: 01147787828

\begin{abstract}
Background: Hepatitis C virus (HCV) is one of the hepatitis viruses that transmitted through blood or blood products. HCV has been implicated as a major reason of chronic liver disease and hepatocellular carcinoma worldwide.

Objective: This study aimed to determine the seroprevalence of HCV antibodies among community in Luxor governorate, Egypt. Moreover to assess if there is any association with the population group, sex, age and other different risk factors.

Patients and methods: We randomly selected 745 blood samples; from males and females of different ages (20-65 years). Samples were collected from Luxor governorate, Egypt. Seras from all subjects were tested for hepatitis $\mathrm{C}$ virus antibodies using rapid test method and confirmed by the enzyme linked immunosorbent assay (ELISA third generation).

Results: Our results showed that $584(78.40 \%)$ of the community were males and most of them aged between 31 and 50 years. Thirty two $(5.48 \%)$ from blood samples of males were anti-HCV seropositive, and the highest prevalence of anti-HCV (7.22\%) of age groups from 41-50 years. One hundred and sixty one $(21.60 \%)$ from the community were female and most of them aged between $41-65$ years. Six $(3.73 \%)$ of female subjects tested positive for anti-HCV and the highest prevalence of anti-HCV $(4.87 \%)$ was with age groups from 31-40 years. Four risk factors reflecting high mechanisms of HCV transmission have been associated with $\mathrm{HCV}$ infection including residing in rural areas, no education, blood transfusion, and dental treatment. Exposures to surgery and history of schistosomiasis showed low association with Anti-HCV. Among the community exposures, were blood donation and alcohol consumption but these associations were not important.
\end{abstract}

Conclusion: This study has been conducted to determine the prevalence rate of anti-HCV among community in Luxor governorate, Egypt.

Key words: HCV, Hepatitis, anti-HCV. 


\section{INTRODUCTION}

Hepatitis C virus (HCV) is a global public health problem. There are about 130 to 150 million people suffering from chronic HCV (WHO, 2015). The highest prevalence of $\mathrm{HCV}$ in the world occurs in Egypt with estimates higher than $10 \%$ among the general population. There are approximately, 3.7 million persons in Egypt have chronic $\mathrm{HCV}$ infection in 2015 (Mastoi et al., 2010; WHO, 2015, and El-Ghitany, 2019).

The high prevalence of HCV is not the only problem, but the high incidence of $\mathrm{HCV}$ is another important issue which reflects the new $\mathrm{HCV}$ infections that occurs annually, where about 160,000 to 500,000 new HCV infections occur annually (Miller and Abu-Raddad, 2010 and Breban et al., 2013).

Reuse of contaminated medical equipment, injection drug use and other health care related procedures (Sharma et al., 2015). Unsafe therapeutic injections and transfusions are likely to be the major modes of transmission, especially in countries where age-specific seroprevalence rates suggest ongoing increased risk of $\mathrm{HCV}$ infection (Mazen et al., 2019).

Contaminated injection equipment appears to be the major risk factor for $\mathrm{HCV}$ transmission in several countries (Shepard et al., 2005). Catching HCV infection after the age of 40 may be associated with a more rapid progression of liver injury, as well as male gender (Svirtlih et al., 2007). Children appear to have a lower risk of disease progression (Pawlowska et al., 2015). Alcohol consumption increases $\mathrm{HCV}$ replication, enhances the progression of chronic $\mathrm{HCV}$, and accelerates liver injury (Gitto et al., 2009). Treatment of schistosomiasis patients by using parenteral antischistosomal therapy (PAT) campaigns is believed to be the major historic cause for increasing the prevalence of HCV in Egypt (Frank et al., 2000).

Our study was undertaken to know the current prevalence of anti-HCV antibodies and risk factors related to anti-HCV antibodies in population of Luxor region of Egypt.

\section{MATERIALS AND METHODS}

This study has been conducted during the period from January through October 2016. The study has been carried out in Luxor governorate, Egypt. The population was males and females over 20 years old. They were randomly selected. All serum samples were transported to the virology laboratory of botany and microbiology department, Al-Azhar University, (Assiut), where all the processing has been carried out.

Consent forms and approval from all subjects included in the study were obtained. All individual were interviewed, and a questionnaire was filled to obtain information on age, place of living, education and health care history. A total of seven hundred and forty five blood samples were collected for the study.

Collection and processing of blood samples: About 3 milliliters of blood were collected and centrifuged at $4000 \mathrm{rpm}$ for 10 minutes. The obtained serum was stored at $-20^{\circ} \mathrm{C}$.

Serum Marker for HCV infection: Anti-HCV was studied using third- 
generation ELISA test (Ortho Diagnostics, Raritan, NJ, USA; and Abbott Diagnostics, North Chicago, IL, USA). Results were read using EL x 800 universal micro- plate reader, (Biotek Instruments Inc.). All positive samples were retested using the same method (double ELISA).

\section{Statistical analysis:}

Data were analyzed using the SPSS version 16. Qualitative variables were described as numbers and percentages. Chi square or Fisher's exact test was used for comparison between groups as appropriate. Odds ratios and their 95\% confidence intervals were calculated. $\mathrm{P}$ value $\leq 0.05$ was considered statistically significant.

\section{RESULTS}

A total of 745 blood samples were included in the study. Their ages ranged from 20-65 years old. Out of these samples, $584(78.40 \%)$ were males, and $161(21.60 \%)$ were females. $66.16 \%$ of the subjects aged $31-50$ years, while those aged $\leq 30$ and $\geq 51$ years were $(17.32 \%$ and $16.52 \%$ respectively). These observed differences are high statistically significant (Table 1).

Gender specific prevalence of antiHCV antibodies: Out of the 745 serum samples, 38 were tested positive, implying an overall prevalence of $5.10 \%$. Thirty two $(5.48 \%)$ of the 584 male subjects were tested positive, while $6(3.73 \%)$ of the 161 female subjects were tested positive. This gender related prevalence of anti- HCV antibodies were highly statistically significant (Table 2).

Age with gender specific prevalence of anti-HCV antibodies: The Males age groups 41-50 years have the highest prevalence of anti-HCV 13 (7.22\%), followed by age-groups $51-65$ years with $5(6.10 \%)$ prevalence, while age-groups from31-40 and 20- 30 years showed lowest prevalence of anti-HCV (5.31\% and $2.60 \%$ respectively). Females predominant cases were in age groups 51 65 years with $2(4.87 \%)$ followed by agegroups 41-50 years with $3(4.10 \%)$ prevalence, while age-groups from 20-30 and 31-40 years showed lowest prevalence of anti-HCV (0\% and $3.03 \%$ respectively). These observed differences were not statistically significant (Table 3).

Many health care risk factors were associated with anti-HCV in the genderadjusted analysis, including residence, education, surgery, blood transfusion and donation, alcohol consumption and history of schistosomiasis (Table 4).

The strength of these associations is for community residing in rural versus urban areas 31 of $542(5.72 \%)$ versus 7 of 203 $(3.45 \%)$ respectively with nonstatistically significant $(\mathrm{P}=0.202)$. History of blood transfusion is reported in $88(11.81 \%)$ community. Anti-HCV is more common in those who have received a blood transfusion than in those who have not received blood: $5(5.68 \%)$ and $33(5.02 \%)$, respectively with high statistically significant $(\mathrm{P}=0.000)$. Dental treatment are associated with anti-HCV status among those $25(5.80 \%)$ compared with $13(4.14 \%)$ no dental treatment with non-statistically significant $(\mathrm{P}=321)$. Education shows association with Anti$\mathrm{HCV}$ and more common in those who have no education than University attendance $72(5.61 \%)$ and $6(3.82 \%)$ respectively with high statistically significant $(\mathrm{P}=0.000)$.

Exposures to surgery, history of schistosomiasis show low association with 
Anti-HCV. Surgery related prevalence of anti-HCV antibodies were high statistically significant $(\mathrm{P}=0.000)$, while observed differences of history of schistosomiasis were not statistically significant $(\mathrm{P}=251)$. Among the community exposures, including blood donation and alcohol consumption but these association are not important (Table $4)$.

Table 1: Age and gender distribution of population in Luxor, Egypt

\begin{tabular}{|c|c|c|c|c|c|}
\hline Age (years) & Male, n (\%) & $\begin{array}{c}\text { Female, } \mathbf{n} \\
(\%)\end{array}$ & Total, n (\%) & $X^{2}$ & $P$ value \\
\hline $20-30$ & $115(19.70 \%)$ & $14(8.70 \%)$ & $129(17.32 \%)$ & \multirow{5}{*}{35.38} & \multirow{5}{*}{$0.001 * *$} \\
\hline $31-40$ & $207(35.44 \%)$ & $33(20.50 \%)$ & $240(32.21 \%)$ & & \\
\hline $41-50$ & $180(30.82 \%)$ & $73(45.34 \%)$ & $253(33.95 \%)$ & & \\
\hline $51-65$ & $82(14.04 \%)$ & $41(25.46 \%)$ & $123(16.52 \%)$ & & \\
\hline Total n: (\%) & $584(100 \%)$ & $161(100 \%)$ & $745(100 \%)$ & & \\
\hline
\end{tabular}

Table (2): Gender related Prevalence of Anti-HCV antibodies

\begin{tabular}{|c|c|c|c|c|c|}
\hline Gender & $\begin{array}{c}\text { Positive, } \mathrm{n} \\
(\%)\end{array}$ & $\begin{array}{c}\text { Negative, } \mathbf{n} \\
(\%)\end{array}$ & $\begin{array}{c}\text { Total, } \mathbf{n} \\
(\%)\end{array}$ & $\mathbf{X}^{2}$ & $P$ value \\
\hline Male & $32(5.48 \%)$ & $552(94.52 \%)$ & $584(100 \%)$ & \multirow{3}{*}{14.55} & \multirow{3}{*}{$0.001 * *$} \\
\hline Female & $6(3.73 \%)$ & $155(96.27 \%)$ & $161(100 \%)$ & & \\
\hline Total, n (\%) & $38(5.10 \%)$ & $707(94.90 \%)$ & $745(100 \%)$ & & \\
\hline
\end{tabular}

** High significant

Table (3): Prevalence of Anti-HCV antibodies related to gender and age

\begin{tabular}{|c|c|c|c|c|c|}
\hline \multirow[b]{2}{*}{$\begin{array}{r}\text { Anti- HCV } \\
\text { Positive, } \\
\text { n (\%) }\end{array}$} & \multirow[b]{2}{*}{ Male } & \multirow[b]{2}{*}{ Female } & \multirow[b]{2}{*}{$\begin{array}{c}\text { Total, } \mathbf{n} \\
(\%)\end{array}$} & \multirow[b]{2}{*}{$\mathbf{X}^{2}$} & \multirow[b]{2}{*}{$P$ value } \\
\hline & & & & & \\
\hline $20-30$ & $3(2.60 \%)$ & $0(0 \%)$ & $3(2.32 \%)$ & \multirow{5}{*}{2.03} & \multirow{5}{*}{0.566 n.s. } \\
\hline $31-40$ & $11(5.31 \%)$ & $1(3.03 \%)$ & $12(5.00 \%)$ & & \\
\hline $41-50$ & $13(7.22 \%)$ & $3(4.10 \%)$ & $16(6.32 \%)$ & & \\
\hline $51-65$ & $5(6.10 \%)$ & $2(4.87 \%)$ & $7(5.70 \%)$ & & \\
\hline Total, n (\%) & $32(5.48 \%)$ & $6(3.73 \%)$ & $38(5.10 \%)$ & & \\
\hline
\end{tabular}

n.s.= Non significant 
PREVALENCE AND RISK FACTORS FOR HEPATITIS C VIRUS...

Table (4): Risk factors related Prevalence of anti-HCVantibdies among population in Luxor governorate, Egypt

\begin{tabular}{|c|c|c|c|c|c|c|c|c|}
\hline \multirow{2}{*}{ Risk factors } & \multicolumn{3}{|c|}{ Participants, n (\%) } & \multicolumn{3}{|c|}{ Anti- HCV Positive, n (\%) } & \multirow{2}{*}{$\mathbf{X}^{2}$} & \multirow{2}{*}{ p value } \\
\hline & Male & Female & Total & Male & Female & Total & & \\
\hline \multicolumn{9}{|c|}{ Residence } \\
\hline Rural & $\begin{array}{c}416(71.23 \\
\%)\end{array}$ & $\begin{array}{c}126 \\
(78.26 \%)\end{array}$ & $\begin{array}{c}542(72.75 \\
\%)\end{array}$ & $\begin{array}{c}26 \\
(6.25 \%)\end{array}$ & $5(3.96 \%)$ & $\begin{array}{c}31(5.72 \\
\%)\end{array}$ & \multirow{2}{*}{4.623} & \multirow{2}{*}{$\begin{array}{l}0.202 \mathrm{n} . \\
\mathrm{s} .\end{array}$} \\
\hline Urban & $\begin{array}{c}168(28.77 \\
\%)\end{array}$ & $\begin{array}{c}35(21.74 \\
\%)\end{array}$ & $\begin{array}{c}203(27.25 \\
\%)\end{array}$ & $6(3.57 \%)$ & $1(2.85 \%)$ & $7(3.45 \%)$ & & \\
\hline \multicolumn{9}{|c|}{ Education } \\
\hline $\begin{array}{l}\text { University } \\
\text { Attendance }\end{array}$ & $\begin{array}{c}148(25.34 \\
\%)\end{array}$ & $9(5.60 \%)$ & $\begin{array}{c}157(21.08 \\
\%)\end{array}$ & $6(4.05 \%)$ & $0(0 \%)$ & $6(3.82 \%)$ & \multirow{3}{*}{298.3} & \multirow{3}{*}{$\begin{array}{c}0.001 * \\
*\end{array}$} \\
\hline $\begin{array}{c}\text { School } \\
\text { Attendance }\end{array}$ & $76(13.01 \%)$ & $\begin{array}{c}31(19.25 \\
\%)\end{array}$ & $\begin{array}{c}107(14.36 \\
\%)\end{array}$ & $4(5.26 \%)$ & $\begin{array}{c}1(3.22 \\
\%)\end{array}$ & $5(5.15 \%)$ & & \\
\hline No education & $\begin{array}{c}360(61.65 \\
\%)\end{array}$ & $\begin{array}{c}121 \\
(75.15 \%)\end{array}$ & $\begin{array}{c}481(64.56 \\
\%)\end{array}$ & $\begin{array}{c}22 \\
(6.11 \%)\end{array}$ & $\begin{array}{c}5(4.13 \\
\%)\end{array}$ & $\begin{array}{c}27(5.61 \\
\%)\end{array}$ & & \\
\hline \multicolumn{9}{|c|}{ History of Blood donation } \\
\hline Yes & $47(8.05 \%)$ & $0(0 \%)$ & $47(6.31 \%)$ & $0(0 \%)$ & $0(0 \%)$ & $0(0 \%)$ & \multirow[b]{2}{*}{210.1} & \multirow{2}{*}{$\begin{array}{c}0.001 * \\
*\end{array}$} \\
\hline No & $\begin{array}{c}537(91.95 \\
\%)\end{array}$ & $\begin{array}{c}161(100 \\
\%)\end{array}$ & $\begin{array}{c}698(93.69 \\
\%)\end{array}$ & $\begin{array}{c}32 \\
(5.95 \%)\end{array}$ & $\begin{array}{c}6(3.73 \\
\%)\end{array}$ & $\begin{array}{c}38(5.44 \\
\%)\end{array}$ & & \\
\hline \multicolumn{9}{|c|}{ History of Blood Transfusion } \\
\hline Yes & $39(6.68 \%)$ & $\begin{array}{c}49(30.43 \\
\%)\end{array}$ & $88(11.81 \%)$ & $3(7.69 \%)$ & $\begin{array}{c}2(4.08 \\
\%)\end{array}$ & $5(5.68 \%)$ & \multirow{2}{*}{70.89} & \multirow{2}{*}{$\begin{array}{c}0.001 * \\
*\end{array}$} \\
\hline No & $\begin{array}{c}545 \\
(93.32 \%)\end{array}$ & $\begin{array}{c}112 \\
(69.57 \%)\end{array}$ & $\begin{array}{c}657(88.19 \\
\%)\end{array}$ & $\begin{array}{c}29(5.32 \\
\%)\end{array}$ & $\begin{array}{c}4(3.57 \\
\%)\end{array}$ & $\begin{array}{c}33(5.02 \\
\%)\end{array}$ & & \\
\hline \multicolumn{9}{|c|}{ Dental Treatment } \\
\hline Yes & $\begin{array}{c}329 \\
(56.34 \%)\end{array}$ & $\begin{array}{c}102 \\
(63.35 \%)\end{array}$ & $\begin{array}{c}431(57.85 \\
\%)\end{array}$ & $\begin{array}{c}21 \\
(6.38 \%)\end{array}$ & $\begin{array}{c}4(3.92 \\
\%)\end{array}$ & $\begin{array}{c}25(5.80 \\
\%)\end{array}$ & \multirow{2}{*}{3.495} & \multirow{2}{*}{$\begin{array}{l}0.321 \mathrm{n} . \\
\mathrm{s} .\end{array}$} \\
\hline No & $\begin{array}{c}255(43.66 \\
\%)\end{array}$ & $\begin{array}{c}59 \\
(36.65 \%)\end{array}$ & $\begin{array}{c}314(42.15 \\
\%)\end{array}$ & $\begin{array}{c}11 \\
(4.89 \%)\end{array}$ & $\begin{array}{c}2(3.39 \\
\%)\end{array}$ & $\begin{array}{c}13(4.14 \\
\%)\end{array}$ & & \\
\hline \multicolumn{9}{|c|}{ Surgery } \\
\hline Yes & $83(14.21 \%)$ & $\begin{array}{c}67(41.61 \\
\%)\end{array}$ & $150(20.13 \%)$ & $4(4.82 \%)$ & $\begin{array}{c}3(4.48 \\
\%)\end{array}$ & $7(4.66 \%)$ & \multirow{2}{*}{63.62} & \multirow{2}{*}{$\begin{array}{c}0.001 * \\
*\end{array}$} \\
\hline No & $\begin{array}{c}501(85.79 \\
\%)\end{array}$ & $\begin{array}{c}94(58.39 \\
\%)\end{array}$ & $\begin{array}{c}595(79.87 \\
\%)\end{array}$ & $\begin{array}{c}28 \\
(5.58 \%)\end{array}$ & $\begin{array}{c}3(3.19 \\
\%)\end{array}$ & $\begin{array}{c}31(5.21 \\
\%)\end{array}$ & & \\
\hline \multicolumn{9}{|c|}{ Alcohol Consumption } \\
\hline Yes & $6(1.03 \%)$ & $0(0 \%)$ & $6(0.81 \%)$ & $0(0 \%)$ & $0(0 \%)$ & $0(0 \%)$ & \multirow[b]{2}{*}{2.06} & \multirow{2}{*}{$\begin{array}{c}0.560 \\
\text { n.s }\end{array}$} \\
\hline No & $\begin{array}{c}578(98.97 \\
\%)\end{array}$ & $\begin{array}{c}161(100 \\
\%)\end{array}$ & $\begin{array}{c}739(99.19 \\
\%)\end{array}$ & $\begin{array}{c}32 \\
(5.54 \%)\end{array}$ & $\begin{array}{c}6(3.73 \\
\%)\end{array}$ & $\begin{array}{c}38(5.14 \\
\%)\end{array}$ & & \\
\hline \multicolumn{9}{|c|}{ History of Schistosomiasis } \\
\hline Yes & $21(3.60 \%)$ & $1(0.62 \%)$ & $22(2.95 \%)$ & $1(4.76 \%)$ & $0(0 \%)$ & $1(4.55 \%)$ & \multirow[b]{2}{*}{4.103} & \multirow{2}{*}{$\begin{array}{c}0.251 \\
\text { n.s }\end{array}$} \\
\hline No & $\begin{array}{c}563(96.40 \\
\%)\end{array}$ & $\begin{array}{c}160 \\
(99.38 \%)\end{array}$ & $\begin{array}{c}723(97.05 \\
\%)\end{array}$ & $\begin{array}{c}31 \\
(5.51 \%)\end{array}$ & $\begin{array}{c}6(3.75 \\
\%)\end{array}$ & $\begin{array}{c}37(5.12 \\
\%)\end{array}$ & & \\
\hline
\end{tabular}




\section{DISCUSSION}

Egypt has the highest prevalence of HCV in the world, with more than $20 \%$ positive for HCV among blood screening and testing for the Egyptian blood donors (WHO, 2016). In 2008, Egypt Demographic and Health Survey (EDHS) using a national representative sample estimated the prevalence of $\mathrm{HCV}$ to be $14.7 \%$ among Egyptian between 15-59 years of age by using HCV antibody test, which means that those people have been exposed to HCV (El-Zanaty and Way, 2009). In 2015, Egypt Health Issues Survey (EHIS) using a nationally representative sample reported that $10 \%$ of Egyptians between 15-59 years of age have been infected with HCV infection, while $7 \%$ are chronic active hepatitis $\mathrm{C}$ patients (EHPM, 2015 and Abo-Amer et al., 2018).

This study was performed in Luxor governorates of Egypt, where most of population live in rural regions. The present study documented small prevalence of $\mathrm{HCV}$ infection $(5.10 \%)$ in the study area as compared with other region in Egypt. Our results confirmed findings in previous studies estimating 9\% prevalence in Upper Egypt as compared to 24\% prevalence in the Nile Delta (AbdelAziz et al., 2000 and Mohamed et al., 2005).

Among the tested samples, $78.40 \%$ were males and, $21.60 \%$ were females. The seroprevalence was higher among males $(5.48 \%)$ as compared to females (3.73\%). These results agreed with EHPM (2015), which estimate that the prevalence of $\mathrm{HCV}$ among males are more than females, and to findings of Vallab et al. (2014) who also report higher prevalence of $\mathrm{HCV}$ in males $(0.7 \%)$ as compared to females $(0.66 \%)$. This male preponderance is explained by high exposure level pertaining to various risk factors of HCV transmission due to their lifestyle. These findings were not consistent with other studies where prevalence of anti-HCV antibody is higher among female as compared to male (Ramarokoto et al., 2008; Ayele and Gebre, 2013 and Abo-Amer et al., 2018).

Current study estimated that, the seroprevalence of $\mathrm{HCV}$ among older age groups was much higher than the younger ones. The seropositive cases in current study remained higher in 41-50 years followed by 51-65 years in males, whereas in females predominant cases were in 51-65 years followed by 41-50 years. Various other studies have also demonstrated high seroprevalence of antiHCV antibody among adult population (Siddiqui et al., 2009; Vallab et al., 2014 and Verma et al., 2014).

In this study, four risk factors reflecting direct mechanisms of $\mathrm{HCV}$ transmission have been associated with HCV infection: Residence, education, blood transfusion and Dental treatment. Mohlman et al. (2015), report that community who born after 1980 have modest to low exposure to risk factors such as PAT, blood transfusion and blood donation. However, the association between aging populations and increased health care utilization (El-Zanaty and Way, 2009), which in turn increase the risk for $\mathrm{HCV}$ transmission. The high $\mathrm{HCV}$ positivity prevalence among individuals born before 1960 suggests that the latter cohorts may substantially contribute to the 
ongoing HCV transmission in Egypt (Breban et al., 2014).

In our study, prevalence of anti-HCV was higher among community residing in rural versus urban areas (5.72\% vs. 3.45 $\%$ respectively). This pattern of high anti$\mathrm{HCV}$ prevalence in rural areas was similar to multiple studies conducted in rural areas of Delta governorates which show a prevalence ranging from 14.4 to $18.5 \%$ (Abdel-Aziz et al., 2000; Stoszek et al., 2006; Badr et al., 2016 and Abo-Amer et al., 2018).

Also, we documented that a low level of education was associated with a higher seroprevalence of $\mathrm{HCV}$ infection. It was found that it was higher in illiterate people (5.61\%) while it was much lower among people who have completed secondary education and higher education (5.15\% and $3.82 \%$ respectively). These findings agreed with the report of El-Zanaty and Way (2009) about the relation between educational level and HCV prevalence. It was found that it was higher in illiterate people $(14.5 \%)$, while it was much lower among people who have completed secondary education and higher $(4.1 \%)$.

In a developed country, the risk factor of transmission through blood transfusion has greatly diminished with the introduction of effective screening. However, blood transfusion remained an important past and a potential current risk for HCV transmission in developing countries, where anti-HCV screening is limited by technical and financial factors (Wasley and Alter, 2000). In our study, we found that seropositive cases of Anti-HCV were more common in those who have received a blood transfusion than in those who have not $(5.68 \%$ and $5.02 \%$ respectively). These results agreed with Mousa et al (2016), those anti-HCV antibody positive patients received blood transfusion more frequently than $\mathrm{HCV}$ antibody- negative patient.

In the present study, we demonstrated that the seropositive cases of anti-HCV remain highest in people who underwent dental treatment as compared with people who did not undergo dental treatment. Various other studies reported that there is an evidence of ongoing HCV incidence at dental and medical facilities (Kalil et al., 2010 and Barakat and El-Bashir, 2011), although most studies have not found dental procedures to be a risk for $\mathrm{HCV}$ in Egypt or elsewhere (Habib et al., 2001 and Enomoto et al., 2001).

In our finding exposures to surgery and history of schistosomiasis showed low association with Anti-HCV, while the community exposures to blood donation and alcohol consumption did not show any association with Anti-HCV. Mohlman et al (2015) reported a non-statistically significant association between $\mathrm{HCV}$ positivity and blood donation. However, many other studies reported that there is a relation between these risk factors and increasing prevalence of anti-HCV (ElZanaty and Way, 2009; Kalil et al., 2010; Amer et al., 2015 and Yuan et al., 2004).

\section{CONCLUSION}

The current study provides information on anti-HCV prevalence in the general population from Luxor Governorate, Upper Egypt. The anti-HCV prevalence in the community was $5.10 \%$ and was higher among male than female subjects. Prevalence increased with age, and there was a sharp increase after 30 years of age. Other relatively common exposures 
included rate of education, blood transfusion, residence and dental treatment. HCV transmission in Egypt has reached diverse population groups including those who were not conventionally identified to be at risk of infection.

\section{REFERENCES}

1. Abdel-Aziz F, Habib M, Mohamed MK, Abdel-Hamid $M$ and Gamil $F$ (2000): Hepatitis $\mathrm{C}$ virus (HCV) infection in a community in the Nile Delta: population description and $\mathrm{HCV}$ prevalence. Hepatology, 32(1): 111-115.

2. Abo-Amer YE, Abd-Elsalam S, Eldosoky H, ELShenawy AK, Awny S, Elagawy W, El Abgeegy M, Elsergany HF, Elashry $H$ and Negm MS (2018): Declining prevalence of hepatitis $\mathrm{C}$ virus among university students in one of the main governorates in Egypt. Infect. and Drug Resist, 11: 2435-2441.

3. Amer FA, Gohar M and Yousef M (2015): Epidemiology of Hepatitis C Virus Infection in Egypt. International Journal of Tropical Disease \& Health 7(3): 119-131.

4. Ayele AG and Gebre Selassie $S$ (2013): Prevalence and risk factors of hepatitis $\mathrm{B}$ and hepatitis $\mathrm{C}$ virus infections among patients with chronic liver diseases in public hospitals in Addis Adaba, Ethiopia. ISRN Tropical Medicine, 1-7.

5. Badr RS, Korah TE, Tawfeek AR and Mohamed KA (2016): A study on how patients catch hepatitis $\mathrm{C}$ virus. Menoufia Medical Journal, 29(2): 215-221.

6. Barakat SH and El-Bashir N (2011): Hepatitis $\mathrm{C}$ virus infection among healthy Egyptian children: prevalence and risk factors. Journal Viral Hepat, 18(11): 779784.

7. Breban R, Arafa N, Leroy S, Mostafa A and Bakr I (2014): Effect of preventative and curative interventions on hepatitis $\mathrm{C}$ virus transmission in Egypt (ANRS 1211): a modeling study. Lancet Glob Health, 2(9): e541-549.
8. Breban R, Riou J and Fontanet A (2013): Interhuman transmissibility of Middle East respiratory syndrome coronavirus: estimation of pandemic risk. Lancet 382(9893): 694699.

9. EHPM, Egyptian Health and Population Ministry (2015): El-Zanaty and Associates [Egypt], ICF International. Egypt Health Issues Survey 2015, Maryland, USA.

10. El-Ghitany EM (2019): Hepatitis C Virus Infection in Egypt: Current Situation and Future Perspective. J of High Institute of Public Health, 49(1):1-9.

11. El-Zanaty F and Way A (2009): Egypt. Demographic Health Survey 2008 (EDHS 2008). Cairo: Ministry of Health and Population, National Population Council. India.

12. Enomoto A, Yoshino S, Hasegawa H, Komatsu $T$ and Sasahara $H$ (2001): Phylogenetic investigation for the risk of hepatitis $\mathrm{C}$ virus transmission to surgical and dental patients. Journal Viral Hepat, 8(2): 148- 153.

13. Frank C, Mohamed MK, Strickland GT, Lavanchy D and Arthur RR (2000): The role of parenteral antischistosomal therapy in the spread of hepatitis $\mathrm{C}$ virus in Egypt. Lancet, 355(9207): 887-891.

14. Gitto S, Micco L, Conti F, Andreone $P$ and Bernardi M, (2009): Alcohol and viral hepatitis: A minireview. Dig Liver Dis, 41(1): 67-70.

15. Habib M, Mohamed MK, Abdel-Aziz F, Magder LS and Abdel-Hamid M (2001): Hepatitis $\mathrm{C}$ virus infection in a community in the Nile Delta: risk factors for seropositivity. Hepatology, 33(1): 248-253.

16. Kalil KA, Farghally HS, Hassanein KM, Abd-Elsayed AA and Hassanein FE (2010): Hepatitis $C$ virus infection among paediatric patients attending University of Assiut Hospital, Egypt. East Mediterr Health Journal, 16(4): 356-361.

17. Mastoi AA, Devrajani BR, Shah SZ, Rohopoto $Q$ and Memon SA (2010): Metabolic investigations in patients with 
hepatitis B and C. World Journal Gastroenterol, 16(5): 603-607.

18. Mazen N, Serag E, Hamdy A, Rasha MA, Ahmed $H$ and Yehia MN (2019): Clinical Characteristics of HCV in Egyptian Patients. EC Gastroenterol. and Diges Sys, 6(2): 168179.

19. Miller FD and Abu-Raddad LJ (2010): Evidence of intense ongoing endemic transmission of hepatitis $\mathrm{C}$ virus in Egypt. Proc Natl Acad Sci USA, 107 (33): 1475714762.

20. Mohamed MK, Abdel-Hamid M, Mikhail NN, Abdel-Aziz F and Medhat A (2005): Intrafamilial transmission of hepatitis $\mathrm{C}$ in Egypt. Hepatology, 42(3): 683-687.

21. Mohlman MK, Saleh DA, Ezzat S, AbdelHamid $M$ and Korba B (2015): Viral transmission risk factors in an Egyptian population with high hepatitis $\mathrm{C}$ prevalence. BMC Public Health, 15: 1030.

22. Mousa SM, El-Ghamrawy MK, Gouda H, Khorshied $M$ and Ahmed DA (2016): Prevalence of Hepatitis C among Egyptian Children with Sickle Cell Disease and the Role of IL28b Gene Polymorphisms in Spontaneous Viral Clearance. Mediterr. Journal Hematol. Infect. Dis, 8(1): e201600.

23. Pawlowska M, Domagalski K, Pniewska A, Smok B and Halota W (2015): What's new in hepatitis $\mathrm{C}$ virus infections in children? World Journal Gastroenterol, 21(38): 10783-10789.

24. Ramarokoto CE, Rakotomanana F, Ratsitorahina $M$, Raharimanga $V$ and Razafindratsimandresy $\quad R \quad$ (2008): Seroprevalence of hepatitis $\mathrm{C}$ and associated risk factors in urban areas of Antananarivo, Madagascar. BMC Infect Dis, 8: 25.

25. Sharma S, Carballo M, Feld JJ and Janssen HL (2015): Immigration and viral hepatitis. Journal Hepatol, 63(2): 515-522.

26. Shepard CW, Finelli $L$ and Alter MJ (2005): Global epidemiology of hepatitis C virus infection. Lancet Infect Dis 5(9): 558567.
27. Siddiqui FA, Akhtar K, Sherwani RK, Rehman K and Alam F (2009): Prevalence of Hepatitis $C$ virus in Aligarh: A seven year experience. Indian Journal Community Med, 34(3): 264-265.

28. Stoszek SK, Abdel-Hamid M, Narooz S, El Daly M and Saleh DA (2006). Prevalence of and risk factors for hepatitis $\mathrm{C}$ in rural pregnant Egyptian women. Trans. R. Soc. Trop. Med. Hyg, 100(2): 102-107.

29. Svirtlih N, Jevtovic D, Simonovic J, Delic $\mathrm{D}$ and Dokic L (2007): Older age at the time of liver biopsy is the important risk factor for advanced fibrosis in patients with chronic hepatitis C. Hepatogastroenterology, 54(80): 2324-2327.

30. Vallab GB, Vazhavandal, A. Uma and Chitra Rajalakshmi (2014): Seroprevalence of Hepatitis C Virus Infection among Patients attending a rural teaching hospital in South India: A Three Year Study. Int. Journal Curr. Microbiol. App. Sci, 3(2): 123-127.

31. Verma R, Behera BK, Jain RB, Arora V and Chayal V (2014): Hepatitis C: A silent threat to community of Haryana, India: A community based study. Australas Med. Journal, 7(1): 11-16.

32. Wasley $A$ and Alter $M$ (2000): Epidemiology of hepatitis $\mathrm{C}$ : geographic differences and temporal trends. Semin Liver Dis, 20(1): 1-16.

33. WHO, World Health Organization (2016): GAR-WHO Hepatitis C. Fact sheet, Geneva, Switzerland.

34. WHO, World Health Organization (2015): Hepatitis C. Fact sheet, Geneva, Switzerland.

35. Yuan JM, Govindarajan S, Arakawa K and Yu MC (2004): Synergism of alcohol, diabetes, and viral hepatitis on the risk of hepatocellular carcinoma in blacks and whites in the U.S.A. Cancer, 101(5): 10091017. 
عو امل المخاطر و إنتشار فيروس التهاب الكبد الوبائي سي بين السكان في محافظة الأقصر بمصر

أحمد محمد العادلي*، أحمد ورداني عبدالراضي*، محمد فخري محمد**

*ققم النبات والميكروبيولوجي، كلية العلوم، جامعة الأزهر (أسيوط)

*:قسم أمراض الكبد والجهاز الهضمي والأمراض المعدية، كلية الطب، جامعة الأزهر (أسيوط)

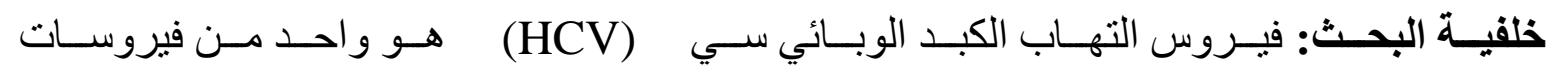

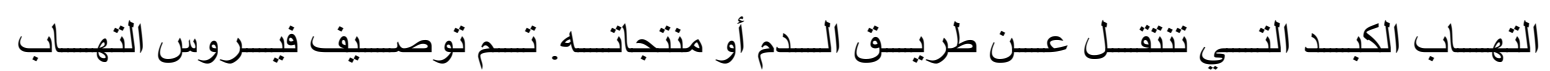

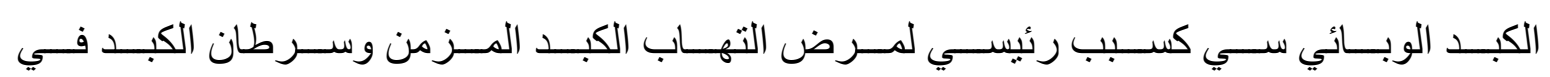

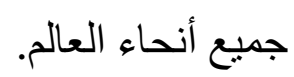

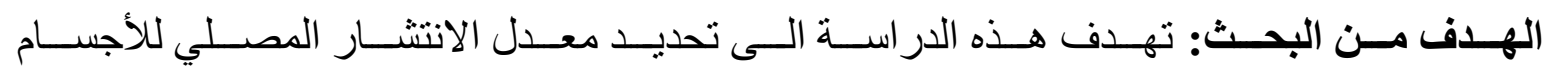

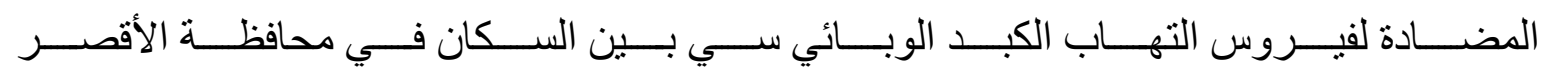

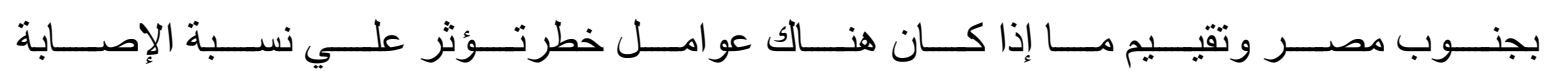

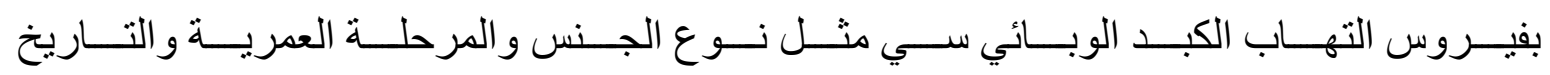

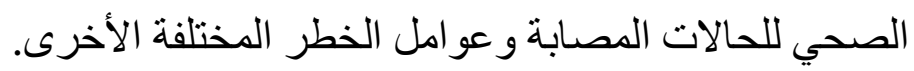

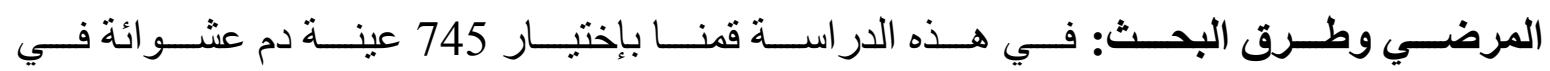

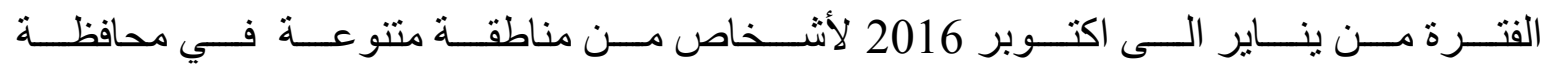

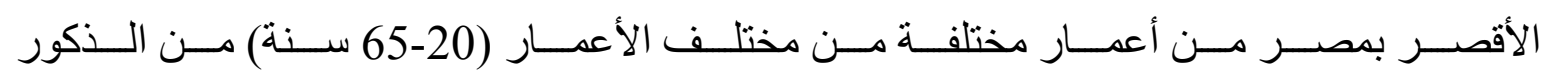

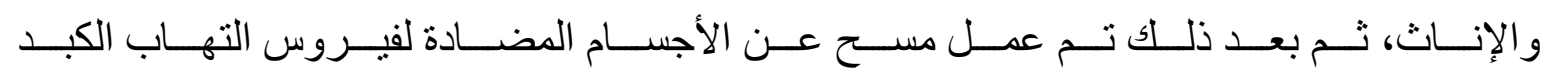
الوبائي سي بإستخدام تقنية اختبار الإليز ا.

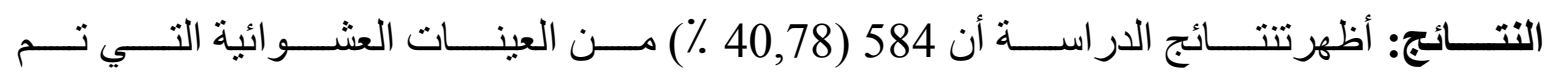

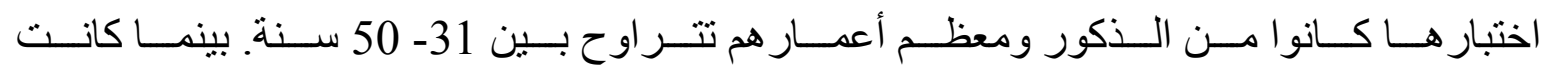

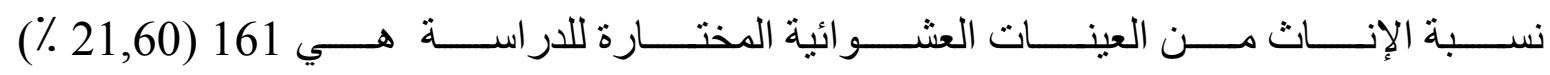

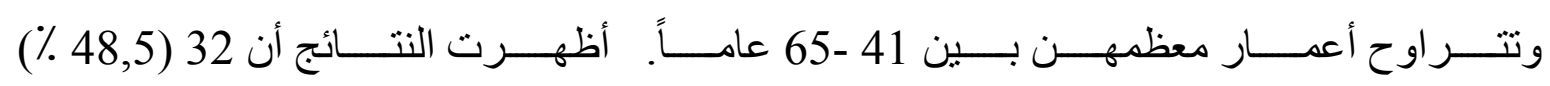

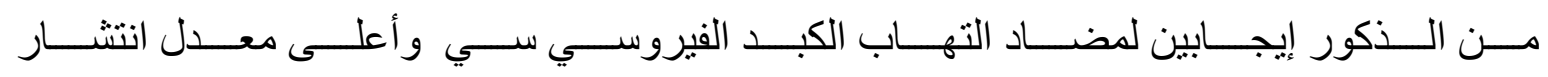

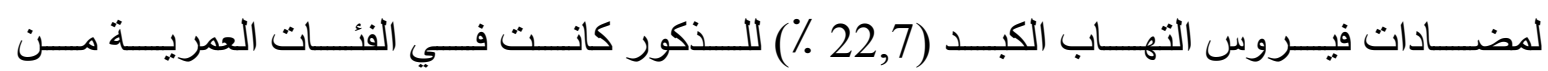




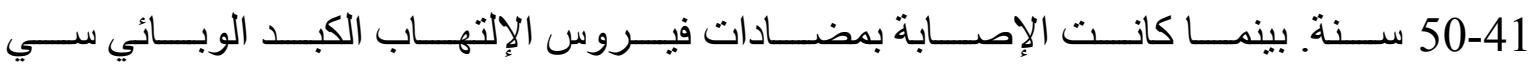

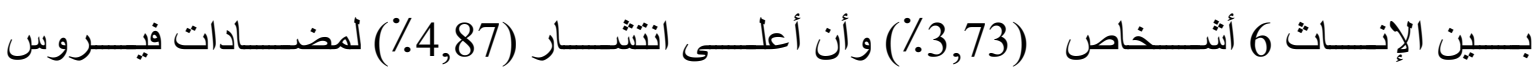

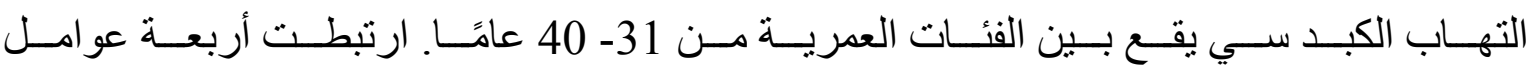

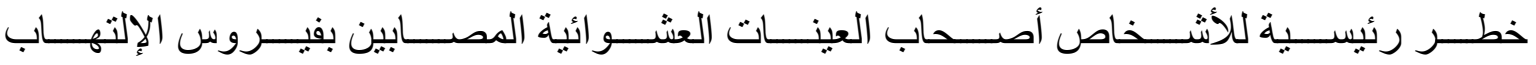

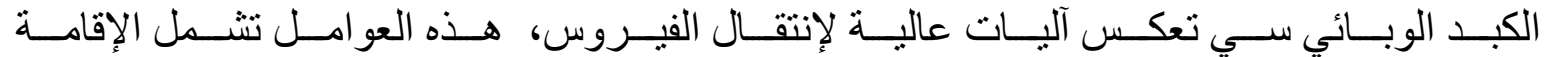

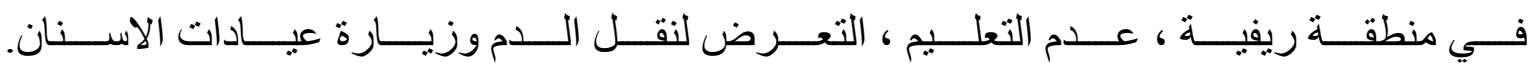

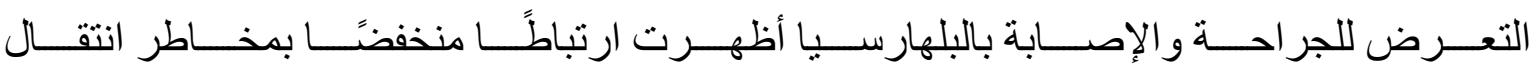
فيروس التهاب الكبد الوبائي سي.

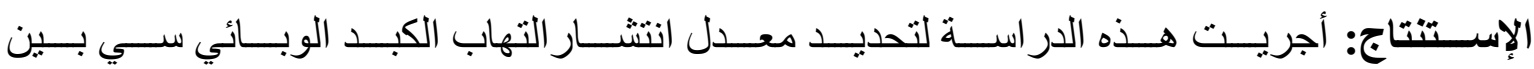

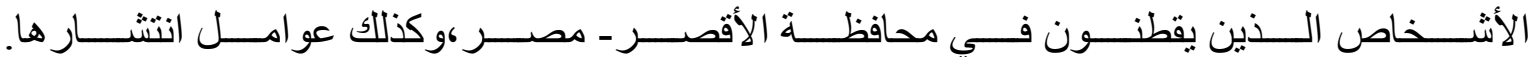

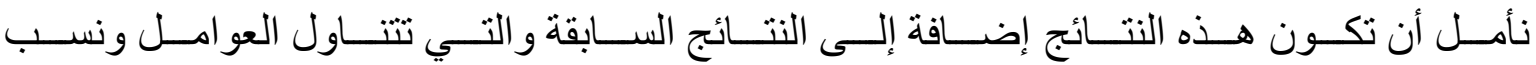
إنتشار فيروس التهاب الكبد الوبائي سي في مصر. 